\section{Ohio 9834 and Ohio 9816: Processing Tomato Breeding Lines with Partial Resistance to Race T1 of Bacterial Spot}

\section{David M. Francis ${ }^{1}$}

Department of Horticulture and Crop Science, The Ohio State University, Ohio Agricultural Research and Development Center, 1680 Madison Ave, Wooster, OH 44691

\section{Sally Miller}

Department of Plant Pathology, The Ohio State University, Ohio Agricultural Research and Development Center, 1680 Madison Avenue, Wooster, OH 44691

Additional index words. CIELAB, chromaticity values, disease resistance, inbred backcross breeding, Lycopersicon esculentum

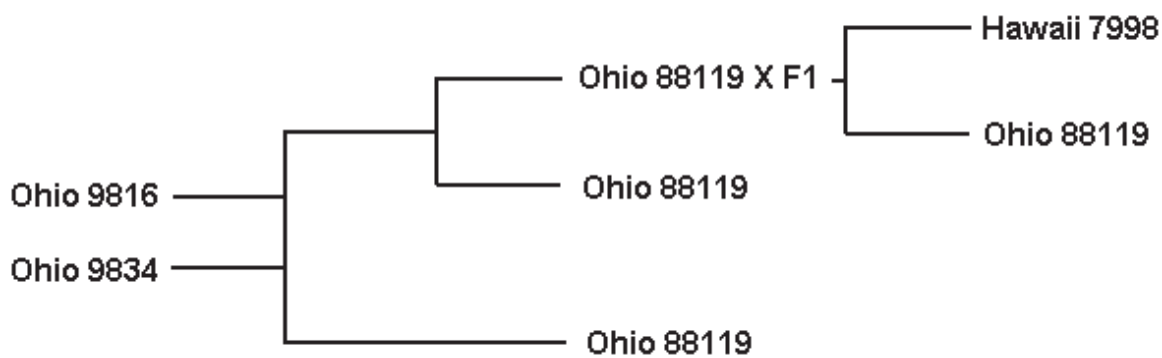

Ohio 9834 and Ohio 9816 are midseason processing tomato (Lycopersicon esculentum Mill.) inbreds adapted to high population transplant culture, machine harvest, and bulk handling under humid growing environments. They are suitable parental lines for the development of hybrids used in the production the midwestern and eastern U.S., in Ontario, Canada, and in Victoria, Australia (Ashcroft et al., 2004; Garrison and Sudal, 2002, 2003; Loewen, 2002, 2003).

\section{Origin}

Ohio 9816 and Ohio 9834 were trailed as 981670.22 and Ohio 987034.1, respectively. They resulted from an inbred backcross breeding program and marker assisted selection to introgress partial resistance from Hawaii 7998 into Ohio 88119 (Berry et al., 1995). Ohio 9816 and Ohio 9834 are sixth generation selections following the final backcross with Ohio 88119.

\section{Description}

The vines of Ohio 9816 are medium to large in size and the vines of Ohio 9834 are small to medium in size. Vines of both lines are prostrate and determinate $(s p)$. Foliage cover is adequate for ensuring good fruit quality at maturity.

Ohio 9816, Ohio 9834, and hybrid varieties developed using these lines as parents were evaluated for performance and fruit quality in multilocation trials in Ohio between 2000 and 2002. Variation in performance associated

Received for publication 8 Dec. 2004. Accepted for publication 15 Jan. 2005. Salaries and research support provided by state and federal funds appropriated to The Ohio State University, Ohio Agricultural Research and Development Center, and grant funds from the Mid-America Food Processors Association. The mention of firm names or trade products does not imply that they are endorsed or recommended by The Ohio State University over other firms or similar products not mentioned.

1Corresponding author; e-mail francis.77@osu.edu.

Table 1. Summary of multilocation trials for yield and quality traits.



${ }^{2}$ Trial locations for multi-location trials were Ohio State University research farms in Fremont, Ohio (FRE) and Wooster, Ohio (WOO), and Hirzel Farms, Wood County, Ohio (HZL).

${ }^{y}$ Yields in tons per hectare are based on a planting density of 30,900/ha for 36 varieties planted in two replicates at Fremont, Ohio, and once-over mechanical harvesting.

${ }^{\mathrm{x}}$ Color values are based on the $\mathrm{L}, \mathrm{a}, \mathrm{b}$ color space with L indicating lightness to darkness; chroma, intensity; and hue, color.

${ }^{\text {w}}$ Color uniformity measures are based on the difference between two measurements per fruit. Low difference values indicate uniform color, or the absence of color disorders.

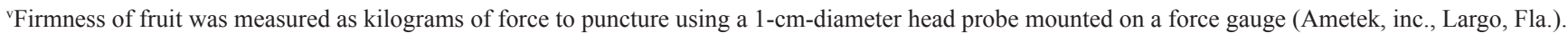


Table 2. Three-year field performance data based on once-over mechanical harvesting in Fremont, Ohio.

\begin{tabular}{|c|c|c|c|c|c|c|}
\hline Genotype & $\begin{array}{l}\text { Yield }^{\mathrm{z}} \\
\left(\mathrm{t} \cdot \mathrm{ha}^{-1}\right)\end{array}$ & $\begin{array}{l}\text { Ripe } \\
(\%)\end{array}$ & $\begin{array}{c}\text { Green } \\
(\%)\end{array}$ & $\begin{array}{l}\text { Cull } \\
(\%)\end{array}$ & $\begin{array}{l}\mathrm{Wt}^{\mathrm{y}} \\
(\mathrm{g})\end{array}$ & $\begin{array}{c}\text { Disease }^{x} \\
\text { index }(0-3)\end{array}$ \\
\hline$\overline{\mathrm{OH}} 7983$ & 72.1 & 81.2 & 13.7 & 4.7 & 62.4 & 1.3 \\
\hline OH 8245 & 97.9 & 85.2 & 8.9 & 6.1 & 62.4 & 1.3 \\
\hline OH 9242 & 76.8 & 76.3 & 13.6 & 9.6 & 68.0 & 1.3 \\
\hline OH 9816 & 110.0 & 82.9 & 11.5 & 5.7 & 56.7 & 1.1 \\
\hline OH 9834 & 95.2 & 79.3 & 8.9 & 11.9 & 56.7 & 1.3 \\
\hline H9423 & 69.5 & 76.4 & 16.9 & 6.4 & 68.0 & 1.8 \\
\hline OX150 & 96.4 & 81.2 & 13.4 & 5.3 & 59.5 & 1.5 \\
\hline $\mathrm{OX} 23$ & 96.9 & 79.6 & 12.7 & 6.3 & 56.7 & 1.5 \\
\hline OX323 & 99.9 & 84.1 & 11.9 & 4 & 59.5 & 1.4 \\
\hline OX324 & 97.2 & 75.6 & 20.4 & 3.9 & 68.0 & 1.0 \\
\hline OX325 & 110.0 & 79.6 & 15.8 & 4.6 & 65.2 & 1.2 \\
\hline OX327 & 97.2 & 74.2 & 20.7 & 5.1 & 62.4 & 1.3 \\
\hline OX328 & 110.5 & 81.6 & 11.5 & 6.9 & 56.7 & 1.4 \\
\hline OX331 & 110.5 & 81.8 & 12.8 & 5.4 & 62.4 & 1.3 \\
\hline OX52 & 83.4 & 80 & 15.6 & 2.3 & 53.9 & 1.3 \\
\hline PS696 & 106.2 & 82.2 & 10.9 & 6.5 & 62.4 & 1.3 \\
\hline TR12 & 82.6 & 79.8 & 14.7 & 5 & 56.7 & 1.3 \\
\hline Mean & 94.9 & 80.1 & 13.8 & 5.9 & 59.5 & 1.3 \\
\hline LSD (0.05) & 20.8 & NS & 5.4 & 5.1 & 5.7 & 0.4 \\
\hline LSD (0.30) & 10.5 & 3.6 & 2.8 & 2.7 & 2.8 & 0.2 \\
\hline
\end{tabular}

${ }^{\mathrm{z}}$ Yields for 17 varieties and controls in tons per hectare are based on a planting density of 30,900/ha.

${ }^{\mathrm{y}}$ Fruit weight in grams.

${ }^{x}$ Disease index is a subjective score of vine health with $0=$ no apparent foliar disease and $3=$ severe defoliation.

Table 3. Three-year quality data, multilocation trial (three locations per year) ${ }^{\mathrm{a}}$.

\begin{tabular}{|c|c|c|c|c|c|c|c|c|c|c|}
\hline \multirow[b]{2}{*}{ Genotype } & \multicolumn{3}{|c|}{ Color $^{b}$} & \multicolumn{3}{|c|}{ Color uniformity $^{\mathrm{c}}$} & \multirow[b]{2}{*}{$\mathrm{pH}$} & \multirow{2}{*}{$\begin{array}{l}\text { Solids } \\
{ }^{\circ} \text { Brix }\end{array}$} & \multicolumn{2}{|c|}{ Firmness $^{\mathrm{d}}$} \\
\hline & $\mathrm{L}$ & Chroma & Hue & Ldif & Cdif & Hdif & & & Crack (\%) & Force \\
\hline$\overline{\mathrm{OH}} 7983$ & 41.4 & 35.1 & 44.0 & 3.9 & 2.8 & 6.7 & 4.35 & 5.32 & 50 & 5.2 \\
\hline $\mathrm{OH} 8245$ & 43.4 & 39.0 & 44.0 & 5.1 & 3.1 & 7.4 & 4.34 & 4.96 & 13 & 5.4 \\
\hline OH 9242 & 39.4 & 35.8 & 40.2 & 3.8 & 3.4 & 4.8 & 4.43 & 5.18 & 50 & 4.5 \\
\hline OH 9816 & 41.3 & 34.7 & 44.4 & 4.0 & 3.0 & 6.1 & 4.39 & 5.03 & 10 & 4.8 \\
\hline OH 9834 & 43.2 & 36.1 & 45.9 & 4.6 & 2.8 & 7.3 & 4.43 & 4.63 & 13 & 4.6 \\
\hline Н 9423 & 43.0 & 40.8 & 40.3 & 3.1 & 2.4 & 4.0 & 4.28 & 4.89 & 23 & 6.0 \\
\hline OX150 & 41.3 & 35.0 & 44.2 & 4.4 & 3.1 & 6.8 & 4.36 & 4.58 & 20 & 4.7 \\
\hline $\mathrm{OX} 23$ & 41.4 & 37.0 & 42.5 & 3.3 & 2.5 & 4.6 & 4.34 & 5.01 & 23 & 5.2 \\
\hline OX323 & 42.6 & 37.4 & 43.8 & 3.9 & 2.7 & 6.5 & 4.40 & 4.85 & 3 & 5.4 \\
\hline OX324 & 41.5 & 36.9 & 42.1 & 4.2 & 3.3 & 5.9 & 4.41 & 4.97 & 5 & 4.9 \\
\hline OX325 & 40.8 & 37.0 & 41.0 & 4.0 & 2.6 & 5.5 & 4.38 & 4.78 & 8 & 4.9 \\
\hline OX327 & 40.7 & 38.4 & 40.4 & 4.0 & 2.6 & 6.1 & 4.42 & 4.89 & 0 & 5.4 \\
\hline OX328 & 41.5 & 35.6 & 43.3 & 4.2 & 2.8 & 7.2 & 4.42 & 4.54 & 23 & 4.6 \\
\hline OX331 & 41.1 & 38.1 & 40.8 & 4.4 & 2.7 & 6.0 & 4.40 & 4.71 & 10 & 5.1 \\
\hline OX52 & 41.6 & 35.4 & 44.1 & 3.8 & 2.6 & 6.8 & 4.34 & 4.72 & 23 & 4.8 \\
\hline PS696 & 42.8 & 37.6 & 45.0 & 4.3 & 2.8 & 6.8 & 4.25 & 4.83 & 18 & 5.3 \\
\hline TR12 & 40.9 & 36.0 & 43.2 & 3.3 & 2.5 & 5.0 & 4.28 & 5.11 & 33 & 5.2 \\
\hline Mean & 41.6 & 36.8 & 42.9 & 4.0 & 2.8 & 6.1 & 4.4 & 4.9 & 19.1 & 5.0 \\
\hline $\operatorname{LSD}(0.05)$ & 1.7 & 0.9 & 2.5 & 0.8 & 0.4 & 1.7 & 0.07 & 0.30 & 25 & 0.4 \\
\hline $\operatorname{LSD}(0.30)$ & 0.9 & 0.5 & 1.3 & 0.4 & 0.2 & 0.9 & 0.04 & 0.16 & 13 & 0.2 \\
\hline
\end{tabular}

${ }^{a}$ Trial locations for multi-location trials were Ohio State University research farms in Fremont, Ohio, and Wooster, Ohio, and Hirzel Farms, Wood County, Ohio.

${ }^{b}$ Color values are based on the L, a, b color space with L indicating lightness to darkness; chroma, intensity; and hue, color.

${ }^{c}$ Color uniformity measures are based on the difference between two measurements per fruit. Low difference values indicate uniform color or the absence of color disorders.

${ }^{\mathrm{d}}$ Firmness of fruit is measured as percentage of fruit cracked following a 1.25-m drop onto concrete or as kilograms of force to puncture using a 1-cm-diameter head probe mounted on a force gauge (Ametek, inc., Largo, Fla.).

with these trials is summarized in Table 1. The average machine harvest yield of Ohio 9816 was $110.0 \mathrm{t} \cdot \mathrm{ha}^{-1}$ over 3 years of testing, outperforming the major early season inbred variety Ohio 7983 and the main-season inbred variety Ohio 8245 (Table 2). Yields of Ohio 9816 were comparable to hybrid varieties (Table 2). The average machine harvest yield of Ohio 9834 was $95.2 \mathrm{t} \cdot \mathrm{ha}^{-1}$ over 3 years of testing, comparable to other inbred varieties (Table 2). Fruit of Ohio 9816 and Ohio 9834 average $56.7 \mathrm{~g}$ with two to three locules. The ovate fruit have a small stem scar and core, are uniform ripening $(u)$, and are attached by a jointless pedicel $(j 2)$.

The sampled raw and processed product is characterized by soluble solids content that is comparable to industry standards in the midwest and eastern U.S. (Table 3). The color and uniformity of color for fruit for both lines is comparable to midseason varieties currently in use in the midwestern and eastern U.S. making these lines appropriate for the development of hybrids for peeled, whole-canned, and diced tomato products (Table 3 ). Evaluation of Ohio 9816 and Ohio 9834 in test crosses indicate a potential for both lines as parents for hybrid varieties (Table 4).

\section{Disease Resistance}

Ohio 9816 and Ohio 9834 have partial resis- tance to race $\mathrm{T} 1$ of bacterial spot [Xanthomonas campestris pv. vesicatoria], resistance to race 1 (I) of Fusarium wilt [Fusarium oxysporum Schlechtend. F. sp. lycopersisci (Sacc.) Snyder and Hansen], and resistance to race 1 (Ve) of verticillium wilt [Verticillium dahliae Kleb]. The source of partial resistance to bacterial spot is Hawaii 7998. Both Ohio 9816 and Ohio 9834 carry an introgression on chromosome five that includes the molecular markers TOM49, Rx3-L1, and CosOH73 (Yang et al., 2005). This region had been implicated in the hypersensitive reaction (HR) in response to T1 strains and designated $R \times 3$ (Wang et al, 1994a and $\mathrm{Yu}$ et al., 1995). Due to the poor correlation between greenhouse HR and resistance 


\begin{tabular}{|c|c|c|c|c|c|c|c|c|c|c|c|}
\hline Genotype & $\begin{array}{c}\text { Ripe } \\
\left(\mathrm{t} \cdot \mathrm{ha}^{-1}\right)^{\mathrm{z}}\end{array}$ & $\begin{array}{l}\text { Ripe } \\
(\%)\end{array}$ & $\begin{array}{c}\text { Green } \\
(\%)\end{array}$ & $\begin{array}{l}\text { Cull } \\
(\%)\end{array}$ & $\begin{array}{c}\text { Fruit wt } \\
\text { (g) }\end{array}$ & $\begin{array}{c}\text { Disease } \\
\text { index } \\
(0-3)\end{array}$ & $\begin{array}{c}\text { Fruit rot } \\
\text { index } \\
(0-3)\end{array}$ & $\mathrm{pH}$ & $\begin{array}{l}\text { Solids } \\
{ }^{\circ} \text { Brix }\end{array}$ & Female & Male \\
\hline OX150 & 112.0 & 90.1 & 5.2 & 4.7 & 68.0 & 1.5 & 0.8 & 4.3 & 4.7 & OH 88119 & $\mathrm{OH} 9242$ \\
\hline FG99-15 & 93.9 & 73.4 & 15.3 & 11.2 & 79.4 & 1.5 & 0.8 & 4.5 & 5.1 & OH 97710 & OH 9242 \\
\hline FG99-45 & 97.2 & 82.5 & 8.8 & 8.7 & 79.4 & 1.5 & 1.0 & 4.5 & 4.9 & OH 97710 & OH E3259 \\
\hline OX330 & 123.5 & 87.6 & 4.3 & 8.1 & 62.4 & 2.3 & 1.3 & 4.4 & 3.9 & OH 981205 & OH 9242 \\
\hline OX336 & 117.2 & 88.5 & 4.3 & 7.2 & 68.0 & 2.0 & 1.0 & 4.4 & 4.4 & OH 981205 & OH 9816 \\
\hline FG99-19 & 114.0 & 80.5 & 13.7 & 5.7 & 70.9 & 1.0 & 1.0 & 4.3 & 4.9 & OH 9816 & OH 9242 \\
\hline OX328 & 111.0 & 74.7 & 19.9 & 5.5 & 68.0 & 1.5 & 0.5 & 4.4 & 4.0 & OH 9816 & OH E3259 \\
\hline FG99-21 & 101.4 & 76.1 & 11.8 & 12.1 & 70.9 & 1.0 & 1.3 & 4.3 & 5.4 & OH 9834 & OH 9242 \\
\hline OX329 & 114.0 & 82.0 & 10.5 & 7.4 & 65.2 & 1.5 & 1.0 & 4.5 & 4.4 & OH 9834 & OH E3259 \\
\hline $\mathrm{OH} 8245$ & 111.5 & 88.5 & 6.8 & 4.7 & 73.7 & 1.5 & 1.0 & 4.4 & 4.7 & & \\
\hline OH 9242 & 71.1 & 73.8 & 17.6 & 8.6 & 82.2 & 1.8 & 1.3 & 4.5 & 5.3 & & \\
\hline OH 88119 & 77.1 & 81.9 & 6.5 & 11.7 & 62.4 & 2.0 & 1.0 & 4.4 & 4.4 & & \\
\hline OH 981205 & 91.1 & 86.8 & 4.5 & 8.7 & 62.4 & 1.3 & 1.5 & 4.5 & 3.7 & & \\
\hline OH 9816 & 100.4 & 80.0 & 16.8 & 3.2 & 65.2 & 1.0 & 0.8 & 4.3 & 5.2 & & \\
\hline OH 9834 & 104.2 & 80.9 & 9.5 & 9.6 & 65.2 & 1.0 & 1.3 & 4.4 & 4.2 & & \\
\hline OH E3259 & 85.9 & 80.4 & 11.6 & 8.0 & 68.0 & 1.8 & 1.0 & 4.4 & 4.4 & & \\
\hline Mean & 101.7 & 81.7 & 10.5 & 7.8 & 68.0 & 1.5 & 1.0 & 4.4 & 4.6 & & \\
\hline LSD $(0.05)$ & 22.8 & 9.0 & 8.9 & 6.6 & 8.5 & 0.7 & 0.8 & 0.1 & 0.8 & & \\
\hline $\operatorname{LSD}(0.30)$ & 12.1 & 4.7 & 4.7 & 3.5 & 5.7 & 0.4 & 0.4 & 0.1 & 0.4 & & \\
\hline
\end{tabular}

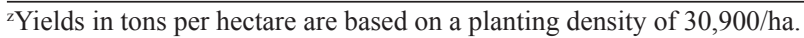

${ }^{y}$ Disease index is a subjective score of vine health with $0=$ no apparent foliar disease and $3=$ severe defoliation.

${ }^{x}$ Fruit rot index is a subjective score of fruit integrity with $0=$ no disease or cracking and $3=$ severe fruit disease and/or cracking.

Table 5. Bacterial spot disease severity ratings.

\begin{tabular}{lcc}
\hline & \multicolumn{2}{c}{ Disease rating $^{z}$} \\
\cline { 2 - 3 } Variety & Year & 3 Year \\
\hline OH 981205 & 8.0 & --- \\
OH 88119 & 7.3 & 7.7 \\
OH 9242 & 6.2 & --- \\
PetoSeed 696 & 6.0 & --- \\
OH E3259 & 5.7 & 5.1 \\
OX 323 & 5.3 & --- \\
OH 8245 & 4.8 & --- \\
OX 329 & 4.5 & --- \\
OX 328 & 4.3 & --- \\
OH 9834 & 4.2 & 4.6 \\
OH 9816 & 3.7 & 4.3 \\
Mean & 5.45 & 5.43 \\
$P$ & 0.0062 & 0.0089 \\
LSD 0.05 & 2.18 & 2.45 \\
\hline
\end{tabular}

${ }^{2}$ Ratings are based on the 1-12 Horsfall-Barratt scale (Horsfall and Barratt, 1945) with lower values indicating less disease. Data are for 2000-01 (2 year) and 1999-2001 (3 year), Fremont, Ohio, from field trials inoculated Xanthomonas campestris $p v$. vesicatoria strains $110 \mathrm{C}, 118$, and 89 .

in the field (Somadi et al., 1994; Wang et al., 1994b), our evaluation emphasized evaluation under the relevant field environment and we found that the chromosome 5 introgression explained up to $41 \%$ of the genetic variation for T1 resistance (Yang et al., 2005). Disease evaluations were conducted in 1999,2000, and 2001 at the Vegetable Crops Branch, Fremont Ohio. Six-meter plots were grown with $0.3 \mathrm{M}$ within plot spacing and $1.5 \mathrm{M}$ between row spacing on standard beds. Plots were replicated three times in a randomized complete block design. Plants were inoculated with a mixture ofT1 strains (110C, 118, and 89) about 3 weeks after transplant. Years and replications within years were considered random effects in the analysis of variance. Ohio 9816 and Ohio 9834 exhibited significantly ( $p=0.0089)$ more resistance than the parent line Ohio 88119 (Table 5). Ohio 9816 also exhibited significantly ( $p$ $=0.05$ ) more resistance than the bacterial spot tolerant hybrid, PetoSeed 696 (Table 4) in 2 years of trials.

\section{Availability}

Small samples of seed for research purposes are available from the corresponding author. Distributions require a signed material transfer agreement, which may be obtained from the Office for Technology Licensing, The Ohio State University, 1960 Kenny Road, Columbus, OH 43210-1063, (614)292-3911; Fax (614)292-8907.

\section{Literature Cited}

Ashcroft, B., M. Top, A. Simson, R Coulston, T. Napier, M. Hickey, M. Quadir, G. Bond, and M. Snudden. 2004. Tomato cultivar evaluation: 2003-2004. Austral. Processing Tomato Grower 25:17-21.

Berry, S.Z., T.S.Aldrich, K.L. Wiese, and W.D. Bash. 1995. 'Ohio OX38' hybrid Processing tomato. Hortscience 30:159.

Garrison, S.A. and J.F. Sudal. 2002.2001 Processing tomato variety trial summary. Mid-Atlantic Fruit
Veg. Convention Proc. p. 112-114

Garrison, S.A. and J.F. Sudal. 2003.2002 Processing tomato variety trial summary. Mid-Atlantic Fruit Veg. Convention Proc. 2:59-60

Horsfall, J.G. and R.W. Barratt, 1945. An improved system for measuring plant disease. Phytopathology 36:655 (abstr.).

Loewen, S.E. 2003. Breeding and cultivar evaluation of processing tomatoes cultivar trial research. Ridgetown College, Univ. Guelph, http://www. ridgetownc.on.ca/research/.

Loewen, S.E. 2002. Breeding and cultivar evaluation of processing tomatoes cultivar trial research. Ridgetown College, Univ. Guelph, http://www. ridgetownc.on.ca/research/.

Somodi, G.C., J.B. Jones, and J.W. Scott, 1994. Screening tomato seedlings for resistance to bacterial spot. HortScience 29:680-682.

Wang, J.F., R.E. Stall, and C.E. Vallejos, 1994a. Genetic analysis of a complex hypersensitive reaction to bacterial spot in tomato. Phytopathology $84: 126-132$.

Wang, J.-F., J.B. Jones, J.W. Scott and R. E. Stall, 1994b. Several genes in Lycopersicon esculentum control hypersensitivity to Xanthomonas campestris pv. vesicatoria. Phytopathology 84:702-706.

Yu, Z. H., J. E. Wang, R. E. Stall and C. E. Vallejos. 1995. Genomic localization of tomato genes that control a hypersenstive reaction to Xanthomonas campestris pv. vesicatoria (Doidge) dye. Genetics 141:675-682.

Yang, W, E.J. Sacks, M. L. Lewis Ivey, S. A. Miller, and D. M. Francis, 2005. Resistance in Lycopesrison esculentum intraspecific crosses to race T1 strains of Xanthomonas campestris pv. vesicatoria causing bacterial spot of tomato. Phytopathology 95:519-527. 